\title{
PENGEMBANGAN APLIKASI ANDROID PENGENALAN RAGAM PROFESI BERDASARKAN RUMPUN ILMU TERAPAN
}

\author{
Khilda Wulidatin Noor ${ }^{1)}$, Dede Rahmat Hidayat ${ }^{2)}$, Wirda Hanim ${ }^{3)}$ \\ 1) Magister Bimbingan dan Konseing Universitas Negeri Jakarta, Indonesia \\ E-mail: khildawulidatin@mahasiswa.unj.ac.id \\ 2) Magister Bimbingan dan Konseing Universitas Negeri Jakarta, Indonesia \\ E-mail: dederhidayat@unj.ac.id \\ 3) Magister Bimbingan dan Konseing Universitas Negeri Jakarta, Indonesia \\ E-mail: hanim12@unj.ac.id
}

\begin{abstract}
Abstrak. Tujuan penelitian ini untuk mengembangkan aplikasi android pengenalan ragam profesi yang dapat dikenalkan dengan mengelompokkan profesi berdasarkan rumpun ilmu terapan yang ada di Indonesia sesuai dengan Undang-Undang Republik Indonesia Nomor 12 Tahun 2012 Tentang Pendidikan Tinggi Pasal 10 ayat (2) yang berbunyi: “....(a) rumpun ilmu agama; (b) rumpun ilmu humaniora; (c) rumpun ilmu sosial; (d) rumpun ilmu alam; (e) rumpun ilmu formal; dan (f) rumpun ilmu terapan, dengan aplikasi android. Ragam profesi adalah suatu kegiatan yang dilakukan seseorang untuk menafkahi diri dan keluargannya dimana profesi tersebut diatur oleh etika profesi dimana etika profesi tersebut hanya berlaku sesama profesi tersebut. Selain itu pengenalan ragam profesi sejak usia Sekolah Dasar merupakan pilihan strategis dalam mempersiapkan generasi masa depan, ragam profesi sangat dibutuhkan oleh siswa sejak usia Sekolah Dasar, sebagai referensi cita-cita. Mengikuti perkembangan zaman, pengenalan ragam profesi dapat diterapkan dalam teknologi. Metode yang digunakan adalah Research and Development, yang mengembangkan aplikasi android berdasarkan rumpun ilmu terapan. Hasil yang akan diperoleh dari penelitian ini berupa produk-produk yaitu berupa permainan si-onet ragam profesi, dalam bidang karir. Jenis permainan arcade puzzle berbentuk 3 dimensi yang mempunyai konsep sederhana namun tetap menarik untuk dimainkan. Diharapkan agar siswa dapat mengenal dan memilih gambaran terkait kehidupan yang akan datang.
\end{abstract}

Kata Kunci: Ragam Profesi; Aplikasi Android; Siswa Sekolah Dasar

\section{PENDAHULUAN}

Anak usia Sekolah Dasar (SD) mulai membatasi pilihan karir berdasarkan pada informasi yang mereka dapatkan dari lingkungan mereka [1]. Informasi tentang karir menjadi penting untuk dipahami anak-anak SD. Akan tetapi, fakta menunjukkan bahwa pembaharuan informasi karir merupakan tantangan yang besar bagi negara dengan pendapatan perkapita relatif rendah dan negara berkembang [2]. Referensi dan studi pengembangan karir anak Indonesia dalam hal jumlahnya dan variasinya belum memadai. Referensi penting tentang perkembangan vokasi pada masa kanak-kanak lebih sulit ditemukan daripada masa remaja dan dewasa [3]. Sejatinya, bimbingan karir perlu diberikan kepada anak SD bahkan dimulai sebelum taman kanak-kanak dengan asumsi bahwa perkembangan karir mempertimbangkan proses sepanjang hayat; program karir komprehensif disesuaikan usia, dan termasuk kegiatan pengalaman [4].

Cita-cita bagi siswa Sekolah Dasar (SD) bukanlah hal yang mudah untuk ditentukan dan menjadi pilihan yang sesuai dengan kemampuan karena banyak siswa yang tidak mengetahui bahwa cita-cita adalah jalan hidup dalam usaha menggapai kehidupan yang baik di masa mendatang. Dapat disimpulkan cita-cita, akan memiliki semangat dan motivasi untuk seseorang meraihnya. Pengenalan ragam profesi sangat dibutuhkan oleh siswa sejak usia Sekolah Dasar, sebagai referensi cita-cita. Hal itu disebabkan agar siswa dapat mengenal dan memilih gambaran terkait kehidupan yang akan datang. 
Ragam profesi adalah suatu kegiatan yang dilakukan seseorang untuk menafkahi diri dan keluarganya dimana profesi tersebut diatur oleh etika profesi dimana etika profesi tersebut hanya berlaku sesama profesi [5]. Selain itu pengenalan ragam profesi sejak usia Sekolah Dasar merupakan pilihan strategis dalam mempersiapkan generasi masa depan [6]. Pengenalan ragam profesi pada anak usia Sekolah Dasar sangatlah kurang, berdasarkan hasil observasi yang dilakukan mendapatkan hasil bahwa kurangnya jam pelajaran bimbingan dan konseling dirasa menjadi alasan mengapa pemberian layanan bimbingan dan konseling termasuk pengenalan ragam profesi sulit dilaksanakan [7].

Menemukan bahwa, secara keseluruhan, penggunaan games dalam belajar mampu secara positif meningkatkan pengalaman belajar siswa. Siswa menjadi sangat aktif dan antusias sehingga menimbulkan subtansi belajar [8]. Membantu level pemahaman siswa terhadap komunitas melalui teamwork [9]. Penggunaan media inovatif dalam kegiatan belajar mengajar sangatlah diperlukan agar adanya sebuah bentuk kemajuan dalam dunia pendidikan.

Penelitian tentang game edukasi pengenalan profesi dan pekerjaan untuk anak TK menunjukan hasil kuisioner sebanyak 30 responden menunjukan bahwa $94 \%$ responden setuju bahwa game profesi dan pekerjaan mudah digunakan dan dimengerti. Sedangkan penelitian tentang experiential learning bagi siswa SD untuk memahami jenis profesi dan kelanjutan pendidikan menunjukan bahwa hasil yang diperoleh dari kegiatan ini adalah pemahaman akan jenis profesi dan pendidikan lanjut para siswa SD 3 dan 4 yang tercermin dalam hasil angket, wawancara dan diskusi bersama menunjukan bahwa sebagian besar siswa $78 \%$ memahami jenis profesi dan kelanjutan pendidikan.

Dari penelitian-penelitian diatas telah membutikan bahwa pengenalan ragam profesi sebaiknya mulai dikenalkan sedini mungkin mengingat betapa pentingnya masalah karir dalam kehidupan manusia, maka sejak dini anak perlu dipersiapkan dan dibantu untuk merencanakan hari depan yang lebih cerah, dengan cara memberikan pendidikan dan bimbingan karir berkelanjutan. Selain itu, Mereka juga senang bermain peran (misalnya bermain dokter-dokteran, bermain jadi guru, bermain jadi polisi, dll) sesuai dengan peran- peran yang mereka lihat di lingkungan mereka. Jabatan atau pekerjaan yang mereka inginkan atau perankan pada umumnya masih sangat dipengaruhi oleh lingkungan, misalnya dari TV, Internet, majalah, film, maupun tokoh-tokoh yang pernah melintas dalam kehidupan mereka.

Anak usia 10-12 tahun termasuk dalam tahap pertumbuhan (growth) karir. Tahap pertumbuhan ini terdiri atas empat sub tahapan perkembangan, yaitu sub tahapan berkembangnya keingintahuan (curiosity), fantasi (fantasies), minat (interests), dan berkembangnya kemampuan (capacities) karir [10]. Sedangkan Kartadinata \& Sugandi [11] mengatakan bahwa perkembangan karir merupakan bagian dari perkembangan manusia.

Mengingat pentingnya pengenalan ragam profesi sejak dini oleh usia Sekolah Dasar, maka diharapkan pelaksanaan pengenalan ragam profesi diberikan di sekolah secara segera. Pengenalan ragam profesi pada dasarnya adalah sebuah proses atau cara yang direncanakan untuk mengenalkan berbagai macam jenis pekerjaan atau karir kepada anak.

Selama ini di sekolah-sekolah dalam memberikan layanan guru bimbingan dan konseling cenderung sangat monoton, yang biasa terjadi kebanyakan guru masih menerapkan metode ceramah, jarang sekali menggunakan metode yang menarik dan media dalam menyampaikan layanan. Menjembatani berbagai masalah tersebut banyak peneliti membuat sebuah inovasi media seperti pembuatan modul, poster, ataupun buku saku. Namun, inovasi tersebut tergolong sudah banyak digunakan. Selain inovasi media juga terdapat inovasi metode seperti bermain peran, diskusi kelompok dan permainan.

Permainan sangat jarang digunakan di sekolah-sekolah padahal metode tersebut dapat menarik dan meningkatkan antusiasme siswa dalam mengikuti layanan bimbingan dan konseling. Seperti yang diungkapkan "Aspek perkembangan anak dapat tumbuh secara maksimal dan optimal melalui kegiatan permainan" [12]. Metode yang inovatif dan kreatif serta memiliki daya manfaat yang tinggi dengan kualitas tinggi dinilai perlu untuk digunakan dalam layanan bimbingan konseling salah satunya metode permainan.

Pengenalan ragam profesi ini dapat dikenalkan dengan mengelompokkan profesi berdasarkan rumpun ilmu terapan yang ada di Indonesia sesuai dengan Undang-Undang Republik Indonesia Nomor 12 Tahun 2012 Tentang Pendidikan Tinggi Pasal 10 ayat (2) yang berbunyi: “....(a) rumpun ilmu agama; (b) rumpun ilmu humaniora; (c) rumpun ilmu sosial; (d) rumpun ilmu alam; (e) rumpun ilmu formal; dan (f) rumpun ilmu terapan [13].

Hal ini tentu saja untuk memudahkan konselor sekolah menyampaikan informasi terkait ragam profesi. Dalam studi ini melalui pengembangan aplikasi android pengenalan ragam profesi sebagai referensi cita-cita untuk siswa Sekolah Dasar kelas tinggi, yang dapat digunakan untuk membantu siswa menambah referensi cita-cita. Dalam aplikasi ini dimana user Interface merupakan bagian dari perangkat komputer dan perangkat lunak, dimana orang dapat melihat, mendengar, menyentuk, berbicara, atau mengerti secara langsung [14]. Selama ini di sekolah-sekolah dalam memberikan layanan guru bimbingan dan konseling cenderung sangat monoton, yang biasa terjadi kebanyakan guru masih menerapkan metode ceramah, jarang sekali menggunakan metode yang menarik dan media dalam menyampaikan layanan sehingga hal tersebut membuat peserta didik menjadi bosan. Menjembatani berbagai masalah tersebut penulis bermaksud untuk mengambangkan aplikasi android dengan spesifik penelitian ini pada akhirnya akan bertujuan untuk menghasilkan sebuah produk yaitu berupa permainan si-onet ragam profesi, dalam bidang karir. Jenis permainan arcade puzzle yang mempunyai konsep sederhana namun tetap menarik untuk dimainkan.

\section{METODE}

Metode yang digunakan adalah Research and Development. Menurut sugiyono [15] "metode penelitian dan pengembangan merupakan metode penelitian yang digunakan untuk menghasilkan produk tertentu, dan menguji keefektifan produk tersebut". Menurut Gay, Mills, dan Airasian (dalam [16]) "dalam bidang pendidikan tujuan penelitian dan 
pengembangan bukan untuk merumuskan atau menguji teori, tetapi untuk mengembangkan produk-produk yang efektif digunakan di sekolah-sekolah".

Model pengembangan dalam penelitian menggunakan model Borg and Gall, dimana model ini berasal dari hasil pemikiran, masih bersifat konsep yang teruji secara empiris dan pelaksanaannya terorganisir mulai dari perencanaan, pelaksanaan sampai pada evaluasi hasilnya.

Penelitian dilakukan dalam beberapa tahap. Dalam penelitian ini, masih dalam tahap desain dan konsep. Kemudian, setelah membuat desain dan konsep, akan melanjutkan pada tahap di mana pengembangan aplikasi untuk membuat aplikasi android pengenalan ragam profesi. Kemudian melakukan uji coba awal dan uji coba massal. Penelitian ini didasarkan pada tinjauan literatur yang diperoleh dari jurnal, buku dan beberapa literatur lainnya. Selain itu, penulis melakukan analisis data yang dikumpulkan dari literatur.

\section{HASIL DAN PEMBAHASAN}

Profesi adalah suatu kegiatan yang dilakukan seseorang untuk menafkahi diri dan keluarganya dimana profesi tersebut diatur oleh Etika Profesi dimana Etika Profesi tersebut hanya berlaku sesama Profesi tersebut. Pengenalan ragan profesi sebagai referensi cita-cita adalah salah satu cara untuk membantu siswa dalammemberikan pengalaman langsung pada siswa, karena yang terdapat didalam permainan tidak beruba materi ceramah, atau hanya bacaan saja, tetapi juga membagun siswa berpikir dan bekerjasama, dan memiliki rangkaian kegiatan.

Sebagai salah satu layanan bimbingan dan konseling dalam bidang karir, pengenalan ragam profesi akan diberikan kepada siswa, tentu saja itu dilaksanakan karena kebutuhan siswa dan dengan diberikannya permainan ini dapat membatu siswa mengelompokkan profesi berdasarkan rumpun ilmu terapan yang ada di Indonesia sesuai dengan Undang-Undang Republik Indonesia Nomor 12 Tahun 2012 Tentang Pendidikan Tinggi Pasal 10 ayat (2) serta untuk belajar mengenal profesi dengan lebih mudah dan interaktif.

UU No 12 Tahun 2012, akan sangat membantu konselor sekolah atau bimbingan dan konseling guru untuk membantu siswa mengenal dan mengelompokan sebagai referensi cita-cita dimasa depan. Melalui penentuan konsep berdasarkan ilmu terapan dan perkembangan karir siswa SD kelas tinggi dapat diimplementasikan melalui teknologi. Karena pada zaman sekarang pengguna teknologi akan memudahkan siswa untuk mengetahui ragam profesi sebagai referensi cita-cita pada masa depan.

Hasil yang akan diperoleh dari penelitian ini berupa produk yaitu berupa permainan si-onet ragam profesi, dalam bidang karir. Jenis permainan arcade puzzle yang mempunyai konsep sederhana namun tetap menarik untuk dimainkan. Dan diharapkan agar siswa dapat mengenal dan memilih gambaran terkait kehidupan yang akan datang.

Penulis mengembangkan permainan aplikasi android $\mathrm{Si}$ Onet Profesi, yang merupakan pengembangan dari UU No 12 tahun 2012 yang ada untuk mengetahui ragam profesi berdasarkan rumpun ilmu dalam referensi cita-cita. Pengembangan alat ini menggunakan aplikasi android. Berikut perancangan "Permainan Si-Onet Profesi":

Pada tahap ini, terlebih dahulu membuat draf awal media yang mencangkup desain media, dan panduan penggunaan aplikasi "Permainan Si-Onet Profesi". Uraian materi yang dicantumkan dalam aplikasi "Permainan Si-Onet Profesi" ini meliputi beberapa profesi yang terdapat didalam rumpun ilmu terapan.

Aplikasi ini memiliki beberapa fitur, antara informasi, hint, shuffle, dan gambar ragam profesi sesuai dengan UU No 12 Tahun 2012. Dibagian informasi siswa diberi informasi durasi permainan, jumlah pemain, manfaat dan petunjuk cara "Permainan Si-Onet Profesi". Kemudian pada hint siswa akan diberitahu bahwa itu adalah kartu yang bisa digunakan satu kali ketika pemain kesulitan dalam mencocokan atau mencari gambar yang berhubungan, yaitu dengan cara meminta bantuan pada pemain yang lain. Shuffle bisa digunakan satu kali untuk mengacak kembali gambar permainan ketika tidak ada lagi kartu yang bisa dicocokan. Pada gambar profesi setelah pemain berhasil mengambil gambar kartu yang berhubungan, akan muncul pertanyaan atau mendapatkan kartu kesempatan yang dapan digunakan saat pemain membutuhkan, namun jika mendapat pertanyaan membacakan pertanyaan yang kemudian dijawab dan didiskusikan oleh semua pemain yang dipimpin oleh guru BK.

Penelitian ini masih dalam tahap awal dari desain dan konsep, jadi yang kita lakukan sekarang adalah mengembangkan dan memperkuat konsep dari UU No 12 tahun 2012 sebagai dasar pembuatan aplikasi. Berdasarkan hasil diatas, peneliti akan terus mengembangkan aplikasi yang akan membantu siswa dalam referensi cita-cita. Dengan sentuhan teknologi, diharapkan aplikasi ini dapat membantu referensi cita-cita siswa dan belajar mengenal ragam profesi dengan lebih mudah dan interaktif, karena dalam aplikasi ini menggunakan gambar animasi yang membuat siswa tertarik menggunakan serta diharapkan siswa termotivasi untuk menyukai profesi yang menjadi cita-citannya dimasa depan.

\section{KESIMPULAN}

Kesimpulannya, penelitian ini akan menghasilkan berupaproduk yaitu berupa permainan si-onet ragam profesi, dalam bidang karir. Jenis permainan arcade puzzle berbentuk 3 dimensi yang mempunyai konsep sederhana namun tetap menarik untuk dimainkan. Dan diharapkan agar siswa dapat mengenal dan memilih gambaran terkait kehidupan yang akan datang. Penelitian pengenalan ragam profesi ini sangat penting bagi siswa. Pengenalan ragam profesi yang akan dipilih siswa nantinya adalah sebagai bahan referensi siswa untuk menentukan cita-citannya. Tentu saja dalam pengenalan ragam profesi siswa dapat memilih sesuai dengan keinginan dan kebutuhan mereka. Guru bimbingan dan konseling menjadi salah satu alternatif dalam memberikan informasi terkait pengenalan ragam profesi untuk masa depan siswa. Dalam penelitian ini, ragam profesi diadopsi dari rumpun ilmu terapan, diharapkan layanan yang diberikan dapat membantu siswa dalam menentukan cita-cita. 
Permainan android si-onet pengenalan ragam profesi sendiri diharapkan bermanfaat bagi siswa maupun guru bimbingan dan konseling untuk mengetahui profesi lain sesuai dengan rumpun ilmu terapan dengan cara yang menarik. Untuk penelitian berikutnya, perlu pembuatan aplikasi yang bisa diaplikasikan kepada masyarakat luas. Tentu saja, perlu memperhatikan berbagai hal seperti waktu pembuatan, sumber bahan, serta model yang dipatenkan. Dengan demikian, untuk penelitian lebih lanjut diharapkan untuk diujikan para ahli dan uji coba masal. Dari uji coba, akan menentukan seberapa efektif aplikasi yang telah dibuat sebelumnya.

\section{DAFTAR PUSTAKA}

[1] Brown, D., \& Associates. (2002). Career Choice and Development Fourth Edition. San Fransisco: Wiley \& Sons, Inc.

[2] Organisation for Economic Co-opeartion and Development. (2004). Career Guidance: A Handbook for Policy Makers. Paris: OECD.

[3] Hartung, P. J., Porfeli, E. J., \& Vondracek, F. W. (2005). Child Vocational Development: A Review and Reconsideration. Journal of Vocational Behavior, 66(2005), 385-419

[4] Zunker, V. G. (2006). Career Counseling: A Holistic Approach Seventh Edition. USA: Thompson Brooks/Cole.

[5] Adriansyah, S. (2012). Aplikasi Media Pembelajaran Paud Untuk Pengenalan Profesi Berbasis Android. Jurnal Informatika. Universitas Muhammadiyah Sidoarjo.

[6] Salahudin, A. (2010). Bimbingan dan Konseling. Bandung: CV Pustaka Setia.

[7] Azhari. (2016). Pengembangan Media Komik Sebagai Sarana Pengenalan Karir Siswa Kelas IV SDN 1 Babatan Surabaya. Jurnal UNESA.

[8] Beck, A. (2016). Using The Board Game "The Last Straw: A Board Game The Social Determinants of Health" as an Engaged Pedagogical Method in The Sociology Classroom. Illinois: Proquest LLC.

[9] Rossiter, John R, Larry Percy. (1998). Advertising Comunication and Promotion Management, Edisi kedua. Singapura: McGraw-Hill.

[10] Super, D. E. (1990). A life-Span, life-Space Approach. Career Choice and Development. In Brown, D. \& Brooks, L. San Fransisco: JosseyBass Publisher.

[11] Kartadinata, S., \& Sugandi, N. (2002). Bimbingan dan Konseling di Sekolah Dasar. Bandung: CV Maulana.

[12] Adriana, D. (2011). Tumbuh Kembang \& Terapi Bermain pada Anak. Jakarta: Salemba Medika.

[13] Undang-undang Republik Indonesia Nomor 12 Tahun 2012 Tentang Pendidikan Tinggi.

[14] Rina, B. (2016). Perancangan Aplikasi Mobile Pengenalan Ragam Profesi Sebagai Referensi Cita-cita Untuk Anak Usia 10-12 Tahun, Seri Kesehatan Profesi Dokter Hewan dan Ahli Gizi. Jurnal Teknik ITS, 5(2).

[15] Sugiyono. (2011). Metode Penelitian Kuantitatif, Kualitatif dan R \& D. Bandung: Alfabeta.

[16] Emzir. (2014). Metodologi Penelitian Kualitatif Analisis Data. Cet. 4 Jakarta: Rajawali Pers. 